\title{
Biomonitoring ecological status of two reservoirs of the Brazilian semi-arid using phytoplankton assemblages ( $Q$ index)
}

\author{
Biomonitoramento do estado ecológico de dois reservatórios do semiárido brasileiro \\ utilizando assembleias fitoplanctônicas (índice Q)
}

Ana Paula Cardoso Silva ${ }^{1}$ and Ivaneide Alves Soares da Costa $^{1}$

${ }^{1}$ Laboratório de Microbiologia Aquática, Departamento de Microbiologia e Parasitologia, Universidade Federal do Rio Grande do Norte - UFRN, Campus Universitário, s/n, Lagoa Nova, CEP 59072-970, Natal, RN, Brazil e-mail: anapaulacs.bio@gmail.com; iasoares@cb.ufrn.br

\begin{abstract}
Aim: Assess whether the assembly index is a suitable tool for biomonitoring of aquatic ecosystems of semi-arid environment. Methods: Monthly, samples were collected between October 2011 and May 2012 in Santa Cruz do Apodi (543'59"S; 46" $\left.00119^{\prime \prime W}\right)$ and Pau dos Ferros (608'30.12" S; 038 $10^{\circ} 59$ 880”W) reservoirs. Results: The Pau dos Ferros reservoir, shallow, turbid and eutrophic showed dominance of the functional group $S_{N}$ throughout the sample period. Total phytoplankton biovolume ranged between 20 and $70 \mathrm{~mm}^{3} \cdot \mathrm{L}^{-1}$, the lowest values coincided with the increase of the mixing zone and transparency, which occasioned a change in composition of the phytoplankton community. Pau dos Ferros reservoir was categorized as poor for most of the sample period. The Santa Cruz do Apodi reservoir was characterized as mesoeutrophic, exhibiting low total phytoplankton biovolume $\left(0.04\right.$ to $\left.0,4 \mathrm{~mm}^{3} \cdot \mathrm{L}^{-1}\right)$ and greater diversity in the phytoplankton composition. It showed moderate condition during most of the period. Conclusion: In summary, the index Q reflected well the changes in phytoplankton composition, being a good indicator for biomonitoring of these systems.
\end{abstract}

Keywords: phytoplankton; water quality; assemblage index; functional groups.

Resumo: Objetivo: Avaliar se o índice de assembléia é uma ferramenta adequada para o biomonitoramento dos ecossistemas aquáticos de ambiente semiárido. Métodos: Coletas mensais foram realizadas entre outubro de 2011 e maio de 2012 nos reservatórios Santa Cruz do Apodi (543'59” S; 46’ 00.119” W) e Pau dos Ferros (608’30.12” S; 038¹0'59.880” W). Resultados: O reservatório Pau dos Ferros, raso, turvo e eutrófico apresentou dominância do grupo funcional $\mathrm{SN}$ durante todo o período amostral. A biomassa fitoplanctônica variou entre 20 e $70 \mathrm{~mm}^{3}$. $\mathrm{L}^{-1}$, os menores valores coincidiram com o aumento da zona de mistura e transparência, que ocasionaram mudança na composição fitoplanctônica. O reservatório Pau dos Ferros foi categorizado, ecologicamente, como ruim durante quase todo o período amostral. O reservatório Santa Cruz do Apodi apresentou baixa biomassa $\left(0.04\right.$ a $\left.0,4 \mathrm{~mm}^{3} . \mathrm{L}^{-1}\right)$ e maior diversidade na composiçẫo fitoplanctônica. Ele apresentou condição moderada, durante a maior parte do período, influenciado por diferentes grupos funcionais típicos de ambientes mesoeutróficos. Conclusáo: Em síntese, o índice $\mathrm{Q}$ refletiu bem às mudanças na composição fitoplanctônica, sendo um bom indicador para o biomonitoramento desses sistemas.

Palavras-chave: fitoplâncton; qualidade de água; índice de assembleia; grupos funcionais.

\section{Introduction}

The phytoplankton community has been used for several decades to the development of ecological models aimed at understanding patterns of succession and diversity (Sommer et al., 1986; Sommer, 1991). For its ability to respond quickly to environmental changes, it is considered efficient and useful when used as an indicator of natural and anthropogenic changes, through temporal and spatial fluctuations in their composition and biomass (Reynolds, 1984; Padisák, 1992; Barbosa \& Padisák, 2004; Kruk et al., 2002).

Several studies have been developed over time in an attempt to predict the phytoplankton composition by addressing phytosociologic species (Hutchinson, 1967; Tuxen, 1955; Braun-Blanquet, 1964; Pianka, 1970). Most predictive models of 
seasonal and spatial variations of phytoplankton species use large taxonomic divisions, however these groups are not considered an ecologically uniform by encompass organisms phylogeny and characteristics (Reynolds, 1984). The use of species lists to determine the quality of water based on the trophic spectrum also has a long history of studies (Padisák et al., 2006).

As pointed out by Reynolds (1999), the great challenge of the studies associated with the selective processes of phytoplankton is the understanding of what factors were decisive for changes in species composition in eutrophic systems since the trophic spectrum assumes an importance on the constitution of plankton in eutrophic or oligotrophic environments (Reynolds et al., 2002).

Recently, Reynolds et al. (2002), proposed a classification scheme of the functional groups of phytoplankton, in which species associations were determined in view of the functional units constitute basic system, which have originated from polyphyletic taxonomic groups and occupy similar ecological niches. In this system, each association is represented by different alphanumeric codons. To date, approximately 50 functional groups have been described (Reynolds et al., 2002; Padisák et al., 2009). Since then, many studies using the classification scheme of planktonic algae for being sensitive to environmental changes, such as smaller seasonal fluctuations or eutrophication, for example, stratification, and to help in understanding why certain species are more favored than others in the assembly of communities and the reason for the spatial and temporal variations. The approach of functional groups has been applied effectively to the temperate region (Becker et al., 2009; Lopes et al., 2005; Sarmento et al., 2006), tropical (Huszar et al., 2003) and subtropical (Fabbro \& Duivenvoorden, 2000; Kruk et al., 2002). In the Brazilian semiarid, Huszar et al. (2000) identified that the constancy of the reservoirs favored the dominance of $S$ and $S_{N}$ assemblies, characterized by efficiently capturing light, are common to turbid and enriched environments. In this region, favored species are the ones that perform well in low latitude meso-eutrophic environments $\left(S_{N}, S_{1}\right.$, $\mathrm{M}, \mathrm{H}_{1}$ ) as reported by Reynolds et al. (2002) and Padisák et al. (2009).

The successful application of functional groups suggested by Reynolds et al. (2002) lies in the fact that it can simplify the handling of long taxonomic lists traditionally used for species with overlapping ecological characteristics defined functional (Padisák et al., 2009).

In this direction, the contribution of Padisák et al. (2006) to develop the index (Q), using the relative weight of the functional group, proposed by Reynolds et al. (2002), for total phytoplankton biomass, point a promising way to evaluate water quality of lakes and reservoirs. The index $\mathrm{Q}$ has 5 degrees of water quality and is designed to monitor the ecological status of European lakes meeting the requirements demanded by the Water Framework Directive - WFD (European Parliament \& Council of the European Union, 2000) with the goal of becoming a useful approach to biomonitoring. Moreover, innovation in phytoplankton ecology studies relates the dynamics of assemblages present considering the existence of lakes and reservoirs with different morphometrics, which may constitute various phytogeographic regions. He is supported by case studies in three European lakes and applied to several lakes and reservoirs, such as Hungarian Lake Balaton (Hájnal \& Padisák, 2008), four Pole shallow lakes (Pasztaleniec \& Poniewozik, 2010), Spanish Sau reservoir (Becker et al., 2010) and Chinese Three Gorges reservoir (Wang et al., 2011).

In Brazil, Crossetti \& Bicudo (2008) conducted a pioneering study applying the $\mathrm{Q}$ index to evaluate water quality in a eutrophic reservoir and indicated that phytoplankton could be successfully used as an indicator of the ecological status of the system in monitoring processes. Therefore, studies applying the approach of assembly index (Q) for assessment of water quality in reservoirs of the Brazilian semiarid region constitute the base of the discussion to support biomonitoring areas susceptible to various impacts, making this a fundamental research because show the use of phytoplankton as a discriminator of ecological status. This paper examines the application of the $\mathrm{Q}$ index as a tool to assess the ecological status in two Brazilian semiarid tropical reservoirs, based on the approach of the functional groups of phytoplankton.

\section{Material and Methods}

\subsection{Study area}

The study was conducted in two reservoirs, located in Rio Grande do Norte state in Brazilian northeastern semiarid region, predominantly hot and dry climate, high evaporation rates, average annual air temperature of approximately $27^{\circ} \mathrm{C}( \pm 5)$. Rainfall is scanty and irregular with annual averages generally below $900 \mathrm{~mm}( \pm 250)$, also occur shallow soils susceptible to erosion. 
Santa Cruz do Apodi and Pau dos Ferros are artificial reservoirs (Figure 1), are water reserves for domestic supply a population of approximately 200.000 inhabitants, and are used for recreation, irrigation and fish farms. Diffuse nutrient load originates from activities such as agriculture and fishing, soil erosion and urban runoff impact the reservoirs promoting eutrophication.

The Pau dos Ferros reservoir is shallow (medium depth $=3.4 \mathrm{~m}$, maximum depth $=19.9 \mathrm{~m})$, with a surface area of $11.653 .600 \mathrm{~m}^{2}$ and a maximum length of $500 \mathrm{~m}$, mean residence time of 1 year and historical annual average volume of $38.080 .000 \mathrm{~m}^{3}$ staying most of the year with $55 \%$ of its maximum volume capacity.

The Santa Cruz do Apodi reservoir is relatively deep (medium depth $=16 \mathrm{~m}$; maximum depth = $57.5 \mathrm{~m}$ ) with a surface area of $34.136 .600 \mathrm{~m}^{2}$ and maximum length of $18 \mathrm{Km}$. The average residence time is considerably long (14 years). The annual historical average volume is $512.830 .000 \mathrm{~m}^{3}$ and it stays most of the year with $75 \%$ of its maximum volume capacity.

\subsection{Sampling and data analyses}

Monthly, samples were collected between October 2011 and May 2012 in Santa Cruz do Apodi and Pau dos Ferros reservoirs, at a point near the main dam embankment. In each reservoir, were delimited six depths along the water column (three in the zone euphotic- 100\%, 10\% and 1\%), according to Cole (1994), and three in the aphotic zone (middle, bottom, and between them). The samples were subsequently integrated to form a single representative rate for each compartment of the water column, totaling 32 samples.

Vertical profiles of water temperature, dissolved oxygen, $\mathrm{pH}$ and electrical conductivity probe were obtained by multiparametric sounder, every 0.5 from surface to bottom. The transparency (m) was measured using the Secchi disk. The mixed layer $\mathrm{Zm}$ was considered to be the depth at which the dissolved oxygen dropped below 1 mg. $\mathrm{l}^{-1}$ (Zohary et al., 1998). The concentrations of nitrogen and total phosphorus in water were obtained by spectrophotometry according to the recommendations Valderrama (1981).

The trophic state of the reservoirs was obtained using the trophic index of Lamparelli (2004), which possess adaptations of Carlson's TSI for tropical environments. For the determination of Chlorophyll-a, the samples were filtered in filter from Whatman 934-AH with $47 \mathrm{~mm}$ diameter and extraction performed with $10 \mathrm{~mL} 95 \%$ ethanol over night (Lorenzen, 1967). The concentrations

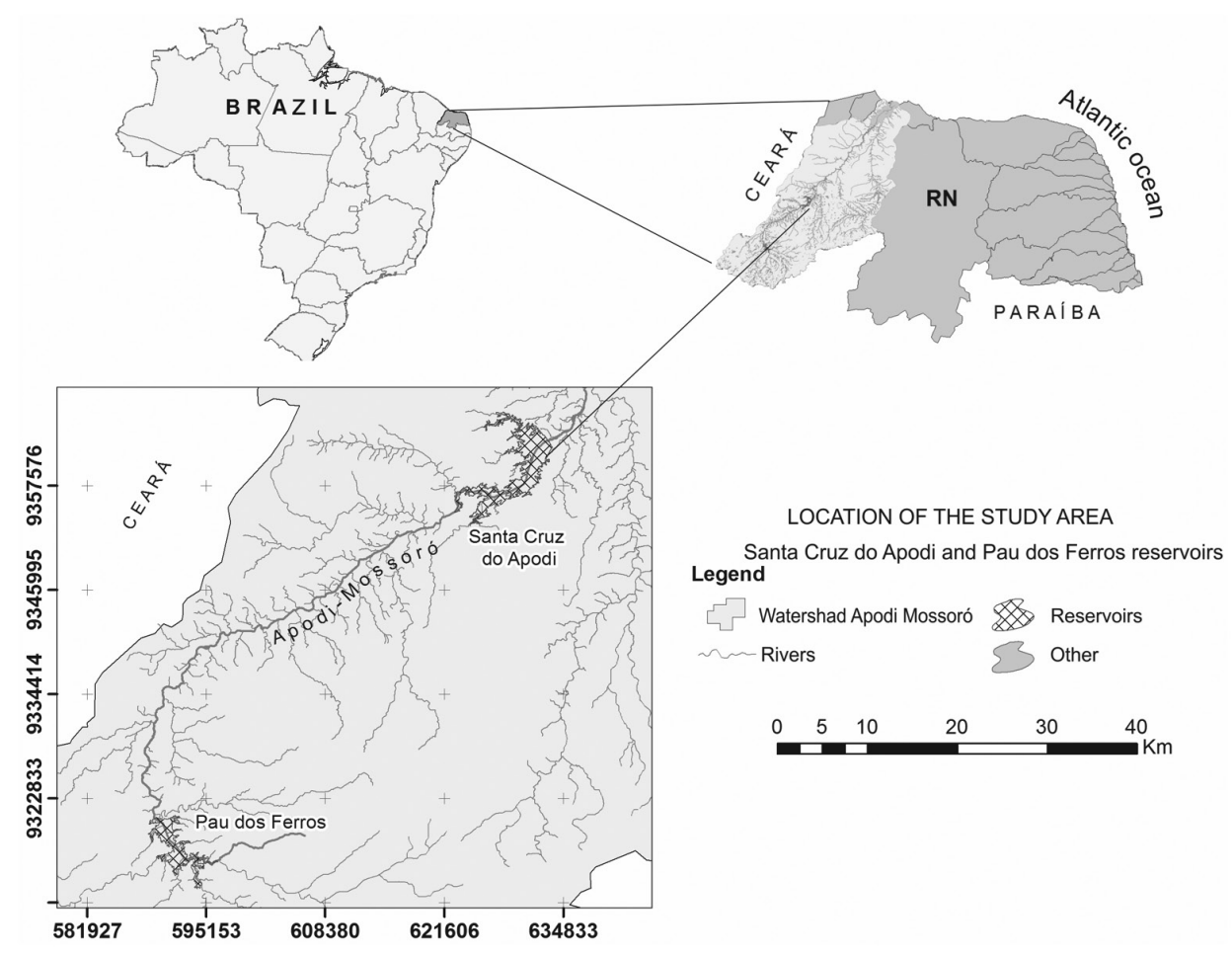

Figure 1. Study area location of the and collection points in the Santa Cruz do Apodi and Pau dos Ferros reservoirs in Rio Grande do Norte state, brazilian northeastern. 
were determined by spectrophotometry $(650 \mathrm{~nm})$ according to the methodology of Jespersen \& Christoffersen (1987).

Qualitative analysis of phytoplankton was done by collecting samples on horizontal and vertical hauls with plankton net $(20 \mu \mathrm{m})$, which were fixed with $4 \%$ formaldehyde. The rating system adopted for cyanobacteria was Komárek \& Anagnostidis (1998) for Chroococcales, Komárek \& Anagnostidis (2005) for Oscillatoriales and Komárek \& Anagnostidis (1989) for Nostocales. For other classes of phytoplankton were used the works of Round (1971) for Chloroficeae, Simonsen (1979) for Diatoms, and Bourelly $(1981,1985)$ for other groups.

Water samples to quantify Phytoplankton were collected with the aid of Van Dorn bottle and preserved with Lugol 1\%. The measurement followed the method of Utermöhl (1958). The count of individuals (cells, colonies and filament) occurred in random fields, the error being less than $20 \%$ at a confidence coefficient of $95 \%$ at the discretion of Lund et al. (1958). The number of fields varied from one sample to another and the completion of the counting was done taking as the criterion score of at least 100 individuals of the dominant species for the Santa Cruz do Apodi dam. As for Pau dos Ferros, we used the criterion of 400 for a $10 \%$ error in view of high dominance of cyanobacteria in this environment (Chorus \& Bartran, 1999).

The phytoplankton biovolume was calculated from geometric models approximate the shape of each species, using for the calculation measures of 30 individuals or cells of each specimen multiplied by its density (Hillebrand et al., 1999). The relative abundance was calculated according to the criteria established by Lobo \& Leighton (1986). The species contributed to $5 \%$ or more of the total phytoplankton biomass were classified in functional groups, using the criteria of Reynolds et al. (2002) and Padisák et al. (2009). The index assembly (Q), developed by Padisák et al. (2006) was used to assess the ecological status of reservoirs.

Prior to analysis, data were log-transformed for statistical normality if necessary. ANOVA and Tukey's test were used to examine significant differences of the variables between reservoirs. Spearman correlation coefficient was used to determine significant correlation between pair variables. Multivariate analysis was used to examine the relation between limnological variables and phytoplankton biomass.

\section{Results}

\subsection{Abiotic variables}

There were significant differences in all investigated limnological variables $(\mathrm{P}>0.05)$ between the reservoirs Pau dos Ferros and Santa Cruz do Apodi during the study. The mean values of the variables: temperature, turbidity, conductivity, total phosphorus (TP), total nitrogen (TN), hidrogenionic potential $(\mathrm{pH})$ and trophic state indexes, are statistically much higher $(\mathrm{P}<0.000)$ in the reservoir Pau dos Ferros. In relation to the variables: volume of water, residence time, mean depth $(\mathrm{Zm})$, and transparency index $\mathrm{Q}$, the averages showed higher values for Santa Cruz when compared to Pau dos Ferros (Table 1).

In Pau dos Ferros reservoir, transparency varied between 0.3 and $0.5 \mathrm{~m}$, the euphotic zone was reduced $(1.2 \mathrm{~m}$ to $1.5 \mathrm{~m}$ ) during the sampling period resulting in lack of seasonal difference $(P>0.05)$. High values of turbidity, total phosphorus, chlorophyll and biovolume of total phytoplankton were recorded in this environment. The chlorophyll, total nitrogen and total biovolume showed similar distribution patterns.

In Santa Cruz, transparency varied ranging between 2.5 and $6 \mathrm{~m}$, the euphotic area 7.5 to $18 \mathrm{~m}$ and increased according to the increase in tank volume, as well as conductivity and total phosphorus. In April 2012, it was announced the fullest extent of the euphotic zone corresponding to the total mixture of water column. This reservoir showed average values of lower turbidity (avg. 6.22), although it was the peak of 114.8 recorded during the month of May 2012.

The thermal gradient of the temperature and oxygen profile of the reservoirs Pau dos Ferros and Santa Cruz (Figure 2 and 3, respectively) showed the same pattern in the two reservoirs studied. The water column proved homogeneous featuring whit no thermocline, water temperature was elevated at the surface and decreased gradually through to the bottom. The temperature difference between each meters depth was always less than $1^{\circ} \mathrm{C}$.

In relation to the dissolved oxygen, a clinograde type and anoxia in the hypolimnion was recorded for the two reservoirs in some periods. The mixing zone ( $\mathrm{Zmix}$ ) was considered the depth at which the oxygen concentration dropped below $1 \mathrm{mg} \cdot \mathrm{L}^{-1}$.

The reservoir Pau dos Ferros, as shallow lake, had a period of total mixture (Dec/11, March and April/12), with OD values in the hypolimnion $\geq 2 \mathrm{mg}$. $\mathrm{L}^{-1}$. In the remainder of the period $\mathrm{Zmix}$ 
Table 1. Mean values ( \pm standard deviation) of environmental variables and outcome of ANOVA to test differences between Santa Cruz do Apodi and Pau dos Ferros reservoirs during the study.

\begin{tabular}{|c|c|c|c|c|}
\hline & Pau dos Ferros & Santa Cruz & \multirow{2}{*}{$F$} & \multirow{2}{*}{$P$} \\
\hline & $\operatorname{Med}( \pm d p)$ & Med ( $\pm d p)$ & & \\
\hline Volume $\left(m^{3}\right)$ & $30,531,044(2,234,029)$ & $458,251,631(13,370,091)$ & 7,965 & * \\
\hline Output $\left(\mathrm{m}^{3} \mathrm{~s}^{-1}\right)$ & $1.06(0.45)$ & $1.03(0.15)$ & 0.037 & ** \\
\hline Residence time (years) & $1(0.44)$ & $14(2.37)$ & 228.1 & * \\
\hline $\mathrm{Zm}(\mathrm{m})$ & $3.67(0.12)$ & $16.43(0.19)$ & 228.1 & * \\
\hline Lamparelli's TSI Trasparency & $73(2.32)$ & $40.48(4,47)$ & 333.1 & * \\
\hline Lamparelli's TSI Chla & $74.7(1.08)$ & $58.8(2.16)$ & 343.6 & * \\
\hline Lamparelli's TSI TP & $67.4(0.44)$ & $63.3(1.77)$ & 40.56 & * \\
\hline Transparency $(\mathrm{m})$ & $0.41(0.06)$ & $4(1.20)$ & 71.87 & * \\
\hline Turbidity (NTU+) & $24.4(9.36)$ & $6.22(9.23)$ & 84.85 & * \\
\hline Condutivity $\left(\mu \mathrm{S} . \mathrm{cm}^{-1}\right)$ & $486(42.1)$ & $281.73(6.14)$ & 308.4 & * \\
\hline $\mathrm{pH}$ & $8.76(0.45)$ & $8.01(0.52)$ & 28.48 & * \\
\hline Watertemperature $\left({ }^{\circ} \mathrm{C}\right)$ & $30(1.25)$ & $28.28(0.92)$ & 23.88 & * \\
\hline $\mathrm{TN}\left(\mu \mathrm{g} \cdot \mathrm{L}^{-1}\right)$ & $1.870(0.80)$ & $1,050(0.77)$ & 7.683 & ** \\
\hline $\operatorname{TP}\left(\mu \mathrm{g} \cdot \mathrm{L}^{-1}\right)$ & 77.42(15.99) & $33.96(14.23)$ & 54.77 & * \\
\hline Chlorophyll a $\left(\mu \mathrm{g} \cdot \mathrm{L}^{-1}\right)$ & $126.42(29.69)$ & $5.51(2.52)$ & 194.2 & * \\
\hline Q Index & $0.5(0.42)$ & $2.34(1.03)$ & 17.73 & * \\
\hline Total biomass $\left(\mathrm{mm}^{3} \cdot \mathrm{L}^{-1}\right)$ & $41.93(15.51)$ & $0.12(0.04)$ & 43.33 & * \\
\hline
\end{tabular}

Probalities are: ${ }^{*} p<0.001 ;{ }^{* *} p<0.005 ;$ ns $=$ not significant differences.
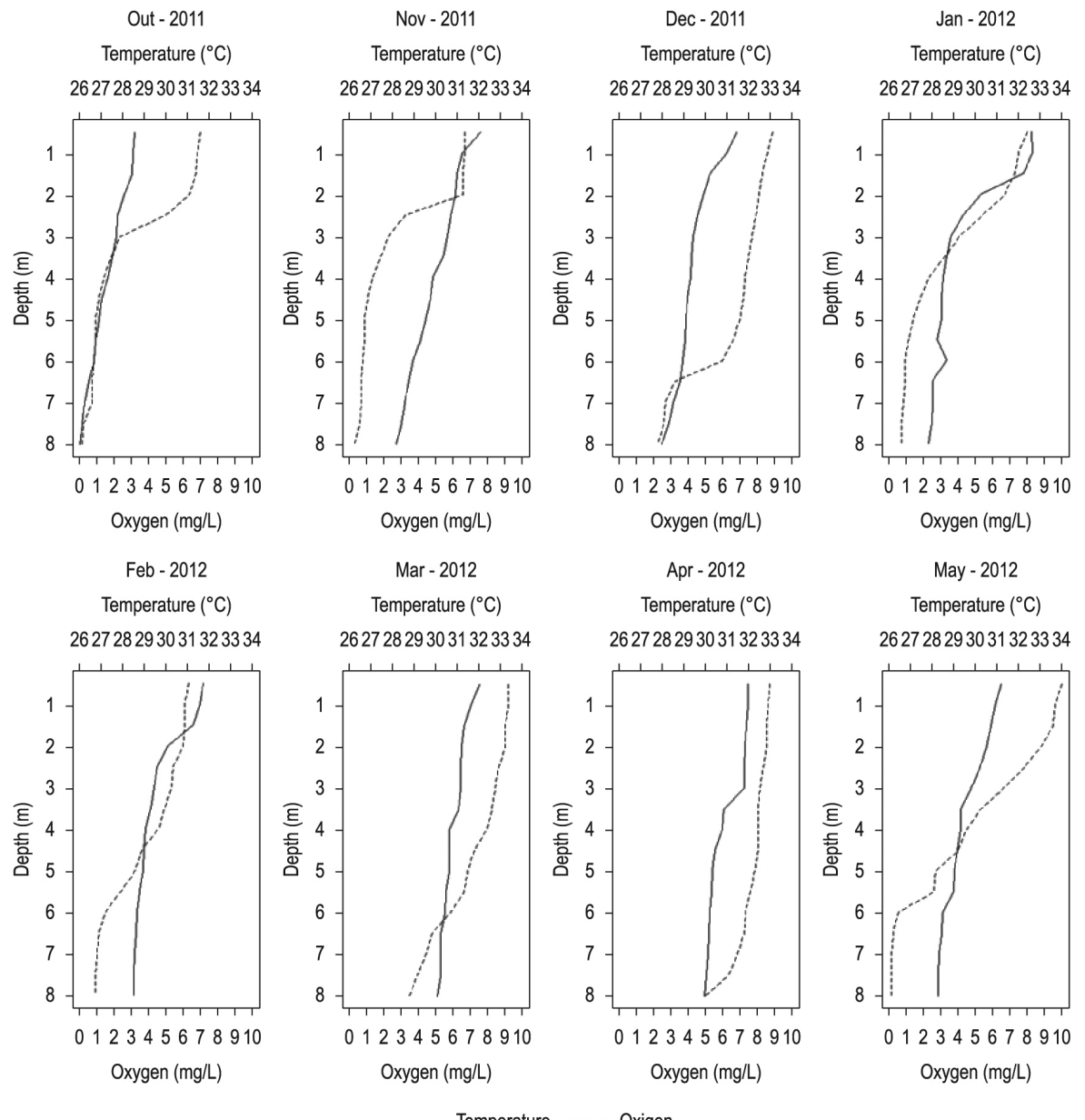

- Temperature -...- Oxigen

Figure 2. Vertical profile of temperature $\left({ }^{\circ} \mathrm{C}\right)$ and dissolved oxygen $\left(\mathrm{mg} \cdot \mathrm{L}^{-1}\right)$ in the reservoir Pau dos Ferros during the study. 


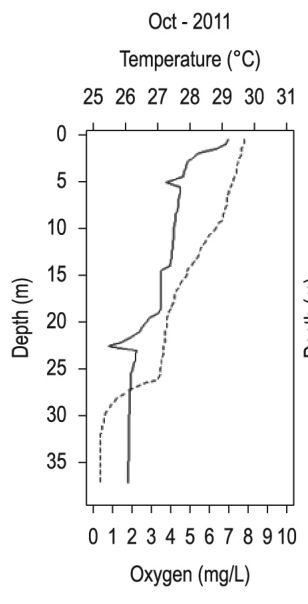

Feb - 2012

Temperature $\left({ }^{\circ} \mathrm{C}\right)$

$\begin{array}{lllllll}25 & 26 & 27 & 28 & 29 & 30 & 31\end{array}$

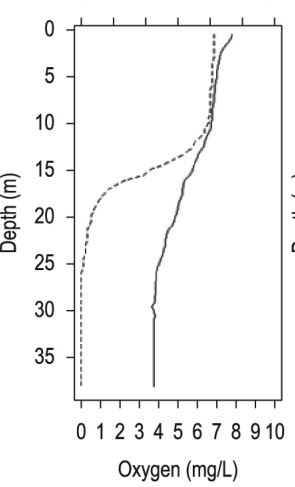

Nov - 2011

Temperature $\left({ }^{\circ} \mathrm{C}\right)$

$\begin{array}{lllllll}25 & 26 & 27 & 28 & 29 & 30 & 31\end{array}$

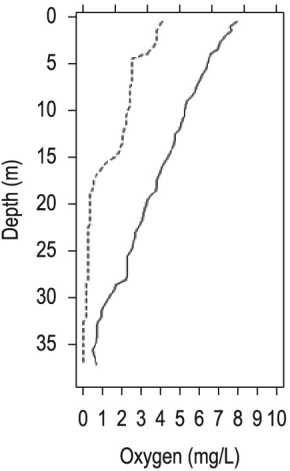

Mar - 2012

Temperature $\left({ }^{\circ} \mathrm{C}\right)$

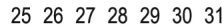

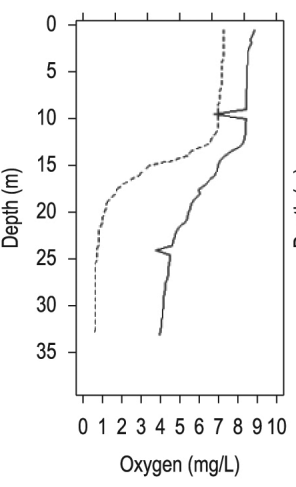

Dec - 2011

Temperature $\left({ }^{\circ} \mathrm{C}\right)$

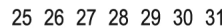

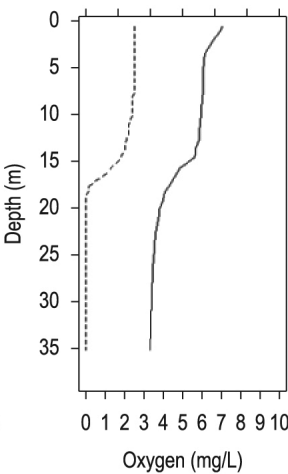

Apr - 2012

Temperature $\left({ }^{\circ} \mathrm{C}\right)$

$\begin{array}{lllllll}25 & 26 & 27 & 28 & 29 & 30 & 31\end{array}$

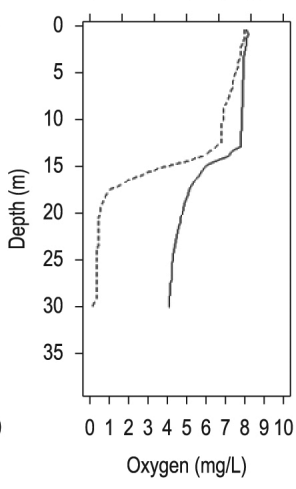

Jan - 2012

Temperature $\left({ }^{\circ} \mathrm{C}\right)$

$\begin{array}{lllllll}25 & 26 & 27 & 28 & 29 & 30 & 31\end{array}$

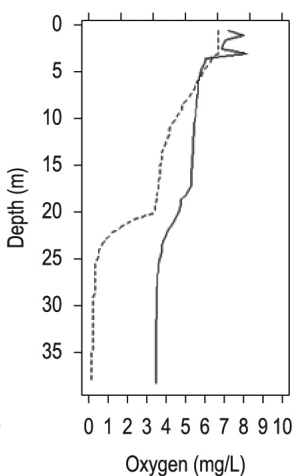

Apr - 2012

Temperature $\left({ }^{\circ} \mathrm{C}\right)$

$\begin{array}{lllllll}25 & 26 & 27 & 28 & 29 & 30 & 31\end{array}$

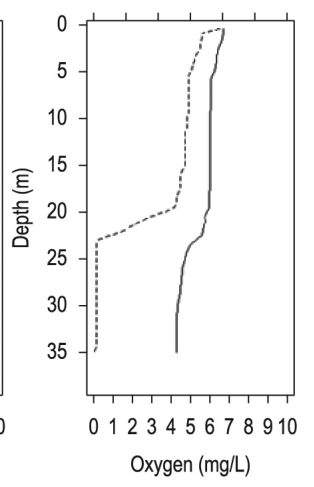

Figure 3. Vertical profile of temperature $\left({ }^{\circ} \mathrm{C}\right)$ and dissolved oxygen $\left(\mathrm{mg} \cdot \mathrm{L}^{-1}\right)$ in the reservoir Santa Cruz do Apodi during the study.

went up to 7 meters deep, reaching anoxia in the hypolimion. In Santa Cruz, which is deeper, the mixed layer ranged from 17 to $25 \mathrm{~m}$. Minor $\mathrm{Zmix}$ occurred in Nov. and Dec/12 (17 meters), increasing in the remainder of the period for $\geq 25$ meters.

The temperature of the water in the reservoir Santa Cruz do Apodi ranged from $31^{\circ} \mathrm{C}(\mathrm{Mar} / 12)$ at the surface to $25^{\circ}$ at the bottom (Nov/11), with gradual reduction of maximum $2^{\circ} \mathrm{C}$ from the surface to the bottom. Similar results as Pau dos Ferros were observed, where the temperature in the water column ranged from $32^{\circ} \mathrm{C}(\mathrm{Apr} / 2012)$ to $28^{\circ} \mathrm{C}$ (Oct/2011) with the highest values between the months of January to April 2012.

When the Trophic State Index (TSI) proposed by Lamparelli (2004) was applied to the variables chlorophyll and phosphorus, the trophic level of the reservoir ranged from eutrophic to hypereutrophic (Pau dos Ferros) and meso to eutrophic (Santa Cruz). Taking into account the values of phytoplankton biomass recorded during the study period, this reservoir was also classified as eutrophic (Pau dos Ferros) and mesotrophic (Santa Cruz do Apodi) (Figure 4).

In Pau dos Ferros reservoir, total nitrogen ranged from 630 to $2.640 \mu \mathrm{g}$. $\mathrm{L}^{-1}$, the highest value being recorded in the period after the occurrence of mixing of the water column. The same pattern was observed for total phosphorus, which ranged between 52 and $99 \mu \mathrm{g} . \mathrm{L}^{-1}$. In Santa Cruz, the total nitrogen ranged between 370 and $2.320 \mu \mathrm{g} . \mathrm{L}^{-1}$. The maximum value was given in the month of Dec/11, total mixing period of the water column. The total phosphorus (13 to $46 \mu \mathrm{g} . \mathrm{L}^{-1}$ ) showed upward trend after the mixing period (Table 1 ).

\subsection{Biological variables}

A total of 47 taxons, distributed between the taxonomic classes: Cyanobacteria, Bacillariophyceae, Chlorophyceae, Chryptophyceae and Euglenophyceae were identified during the study, which were classified into 17 functional groups (Table 2). Some 


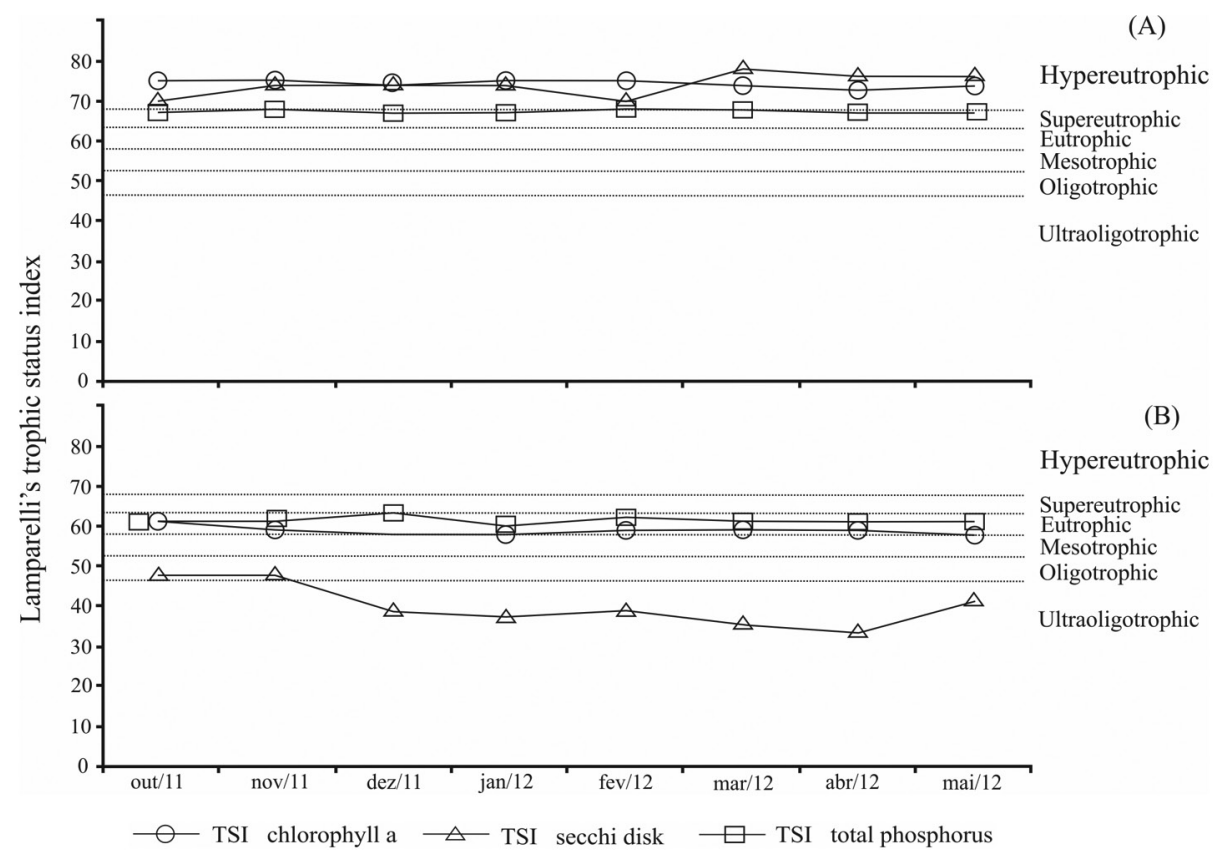

Figure 4. Temporal variation of the Trophic State Index (TSI) proposed by Lamparelli (2004) in Pau dos Ferros (A) and Santa Cruz do Apodi (B) reservoirs. (Ultraoligotrophic TSI $=\leq 47$; Oligotrophic $=47<$ TSI $\leq 52$; Mesotrophic $=52<\mathrm{TSI} \leq 59$; Eutrophic $=59<\mathrm{TSI} \leq 63$; Supereutrophic $=63<\mathrm{TSI} \leq 67$; Hypereutrophic I TS $=>67$ ).

Table 2. Functional groups of phytoplankton (Reynolds et al., 2002), factor (F) used in the calculation of the index Q, frequency of occurrence according to Lobo \& Leighton (1986) of the species identified during the study in the Pau dos Ferros and Santa Cruz reservoirs, from October 2011 to May 2012.

\begin{tabular}{|c|c|c|c|c|c|}
\hline \multirow{2}{*}{$\begin{array}{c}\text { Funcional } \\
\text { group }\end{array}$} & \multirow{2}{*}{ Species } & \multirow{2}{*}{ Taxonomic group } & \multirow{2}{*}{ Factor (F) } & \multicolumn{2}{|c|}{ Frequency Occurrence } \\
\hline & & & & Santa Cruz & Pau dos Ferros \\
\hline \multirow[t]{2}{*}{$\mathrm{K}$} & Aphanocapsa delicatissima & Cyanobacteria & 5 & dominant & \\
\hline & Aphanocapsa incerta & Cyanobacteria & 5 & abundant & rare \\
\hline \multirow[t]{2}{*}{ M } & Microcystis wesenbergii & Cyanobacteria & 0 & dominant & \\
\hline & Microcysitis protocystis & Cyanobacteria & 0 & rare & \\
\hline $\mathrm{H} 1$ & Aphanizomenon gracile & Cyanobacteria & 1 & dominant & abundant \\
\hline \multirow[t]{5}{*}{$\mathrm{S} 1$} & Planktolyngbya limnetica & Cyanobacteria & 0 & abundant & abundant \\
\hline & Geitlerinema unigranulatum & Cyanobacteria & 0 & rare & rare \\
\hline & Pseudanabaena galeata & Cyanobacteria & 0 & & abundant \\
\hline & Pseudanabaena catenata & Cyanobacteria & 0 & rare & \\
\hline & Phormidium $s p$ & Cyanobacteria & 0 & rare & \\
\hline \multirow[t]{5}{*}{$\mathrm{L}_{0}$} & Synechocystis aquatilis & Cyanobacteria & 3 & rare & rare \\
\hline & Merismopedia tenuissima & Cyanobacteria & 3 & abundant & abundant \\
\hline & Merismopedia glauca & Cyanobacteria & 3 & & rare \\
\hline & Chroococcus minutus & Cyanobacteria & 3 & rare & rare \\
\hline & Merismopedia punctata & Cyanobacteria & 3 & rare & dominant \\
\hline$S_{N}$ & Cylindrospermopsis raciborskii & Cyanobacteria & 0 & rare & \\
\hline $\mathrm{L}_{M}$ & Coelomorom tropicalis & Cyanobacteria & 0 & rare & abundant \\
\hline MP & Spirullina $s p$ & Cyanobacteria & 5 & & rare \\
\hline \multirow[t]{3}{*}{$\mathrm{P}$} & Aulacoseira granulata & Bacillariophyceae & 5 & abundant & \\
\hline & $\begin{array}{l}\text { Aulacoseira granulata variação } \\
\text { angutissima }\end{array}$ & Bacillariophyceae & 5 & & abundant \\
\hline & Closterium acutum & Chlorophyceae & 5 & & rare \\
\hline $\mathrm{D}$ & Nitzschia acicularis & Bacillariophyceae & 4 & abundant & abundant \\
\hline $\mathrm{C}$ & Cyclotella ocellata & Bacillariophyceae & 4 & abundant & \\
\hline
\end{tabular}


Table 2. Continued...

\begin{tabular}{|c|c|c|c|c|c|}
\hline \multirow{2}{*}{$\begin{array}{c}\text { Funcional } \\
\text { group }\end{array}$} & \multirow{2}{*}{ Species } & \multirow{2}{*}{ Taxonomic group } & \multirow{2}{*}{ Factor (F) } & \multicolumn{2}{|c|}{ Frequency Occurrence } \\
\hline & & & & Santa Cruz & Pau dos Ferros \\
\hline \multirow[t]{10}{*}{$\mathrm{J}$} & Coelastrum astroideum & Chlorophyceae & 2 & rare & \\
\hline & Coelastrum microporum & Chlorophyceae & 2 & rare & \\
\hline & Ankistrodesmus gracile & Chlorophyceae & 2 & rare & \\
\hline & Crucigenia tetrapedia & Chlorophyceae & 2 & rare & \\
\hline & Scenedesmus acuminatus & Chlorophyceae & 2 & & abundant \\
\hline & Selenastrum sp. & Chlorophyceae & 2 & & rare \\
\hline & Scenedesmus brevispina & Chlorophyceae & 2 & & rare \\
\hline & Scenedesmus ovalternus & Chlorophyceae & 2 & & rare \\
\hline & Scenedesmus quadricauda & Chlorophyceae & 2 & & rare \\
\hline & Tetraedron triangulare & Chlorophyceae & 2 & & rare \\
\hline \multirow[t]{4}{*}{$\mathrm{F}$} & Oocystis lacustris & Chlorophyceae & 3 & abundant & \\
\hline & Eutetramorus sp. & Chlorophyceae & 3 & rare & \\
\hline & Dictyosphaerium pulchellum & Chlorophyceae & 3 & rare & \\
\hline & Botryococcus braunii & Chlorophyceae & 3 & dominant & \\
\hline \multirow[t]{4}{*}{$\mathrm{X} 1$} & Monoraphidium contortum & Chlorophyceae & 3 & rare & abundant \\
\hline & Monoraphidium circinalis & Chlorophyceae & 3 & rare & abundant \\
\hline & Monoraphidium irregulare & Chlorophyceae & 3 & & abundant \\
\hline & Monoraphidium nanum & Chlorophyceae & 3 & & abundant \\
\hline \multirow[t]{3}{*}{$\mathrm{N}$} & Staurastrum leptocladum & Chlorophyceae & 2 & rare & rare \\
\hline & Staurastrum planctonicum & Chlorophyceae & 2 & & rare \\
\hline & Cosmarium punctunlatum & Chlorophyceae & 0 & & rare \\
\hline \multirow[t]{2}{*}{$\mathrm{Y}$} & Chryptomonas sp. & Chryptophyceae & 3 & rare & abundant \\
\hline & Chryptomonas ovata & Chryptophyceae & 3 & & rare \\
\hline W2 & Trachelomonas volvocinopsis & Euglenophyceae & 3 & rare & rare \\
\hline
\end{tabular}

groups like the subdivisions $S 1$ and $S_{\mathrm{N}}$ persisted throughout the sample period.

In both reservoirs studied, the period of greatest Zmix corresponded to higher concentrations of phosphorus and total nitrogen, chlorophyll, total phytoplankton biovolume and greater diversity of functional groups. Increased functional group biovolume $S_{N}$ was observed during periods of reduced $Z$ mix.

The Pau dos Ferros reservoir (Figure 5) showed dominance of functional group $S_{\mathrm{N}}$, whose representative Cylindrospermopsis raciborskii showed a relative contribution between 40 to $90 \%$ of total phytoplankton. In this reservoir, were recorded high values of total phytoplankton biovolume (20 to 70 $\mathrm{mm}^{3} . \mathrm{L}^{-1}$ ) and chlorophyll (Max $\left.150.48 \mathrm{~mm}^{3} \cdot \mathrm{L}^{-1}\right)$. Change in species composition and taxonomic group coincided with the period of greatest Zmix, with increase in the relative contribution of groups $\mathrm{D}$ and $\mathrm{X} 1$, represented by diatoms and green algae, respectively. The group $\mathrm{H} 1$, represented by Aphanizomenon gracile was present in both reservoirs contributing up to $40 \%$ biomass between the months of October 2011 and February 2012.

The Santa Cruz do Apodi reservoir had lower values of total phytoplankton biovolume ( 0.04 to $0,4 \mathrm{~mm}^{3} \cdot \mathrm{L}^{-1}$ ) and chlorophyll (Max $10.39 \mu \mathrm{g} \cdot \mathrm{L}^{-1}$ ) in comparison to Pau dos Ferros. Aphanocapsa delicatissima and Aphanocapsa incerta, codon $\mathrm{K}$, as Planktolyngbya limnetica, codon S1, were present throughout the sample period. The green algae and diatoms (C, F, J, E, D and N) typical in meso-eutrophic environments, contributed to $60 \%$ biomass, showing a possible tolerance to the amounts of nutrients and luminosity or the fact that they have characteristics of low latitudes environments. It might also identify two distinct phases of dominance, the first, between the months of lowest Zmix (October 2011 to March 2012), in which the phytoplankton dominance was represented by colonial and filamentous cyanobacteria and the second, framed between April and May 2012, more Zmix where colonial (F) and individual $(\mathrm{N})$ chlorophytes had representative biomass.

The flow variables (P 0.031) and total Nitrogen and (P 0.046) explained 60\% of variation in total biovolume of phytoplankton in the reservoir Pau dos Ferros during the study. In the reservoir Santa Cruz, temperature (P 0.046), transparency (0.019) and total phosphorus 0.013 explained $70 \%$ of variation.

Nitrogen and total phosphorus were positively correlated with the biomass $(\mathrm{P}=0.046$ and $\mathrm{P}=$ 


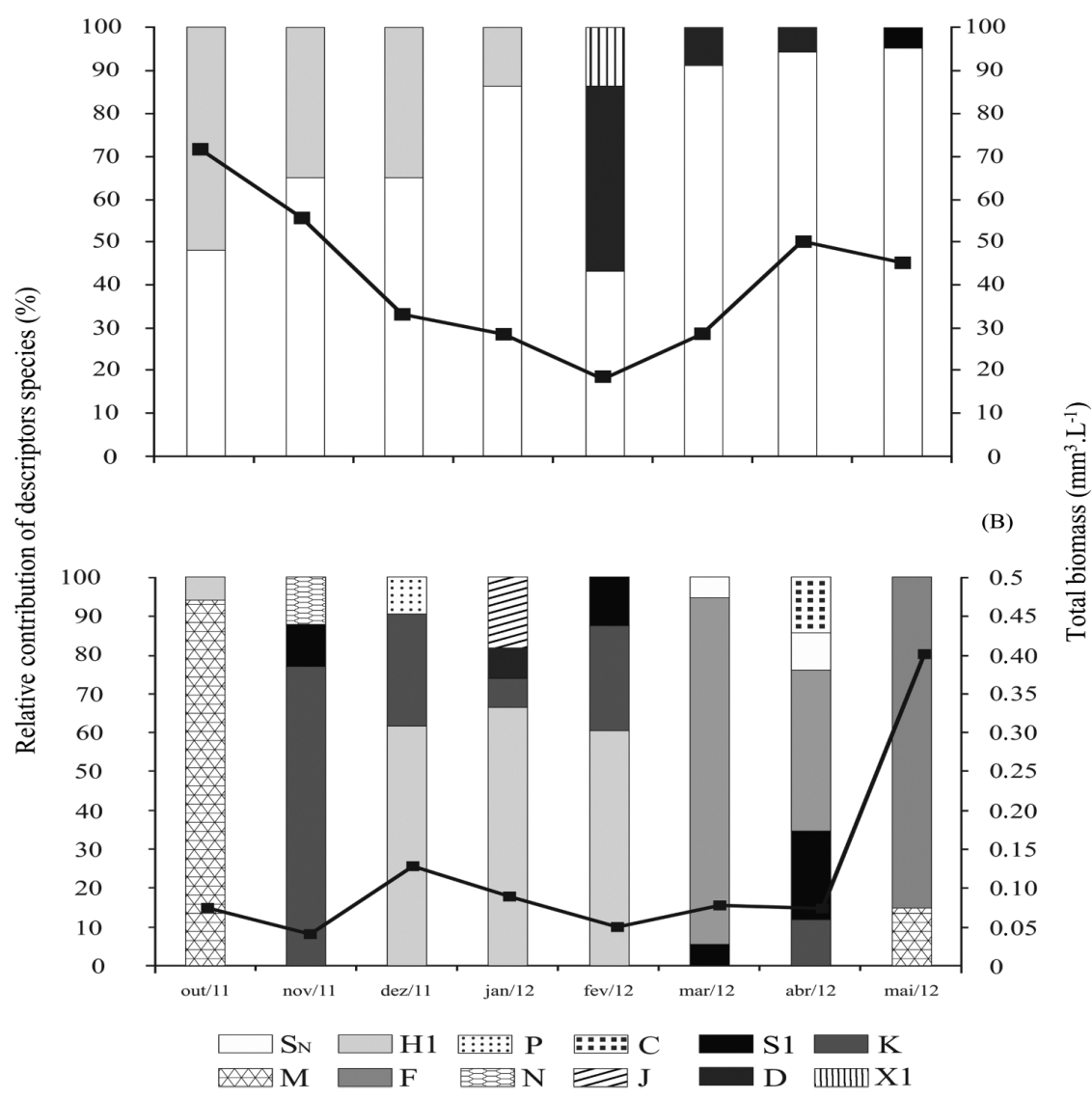

Figure 5. Relative contribution of phytoplankton functional groups (Reynolds et al., 2002) and total biomass $\left(\mathrm{mm}^{3} . \mathrm{L}^{-1}\right)$ from October 2011 to May 2012 in the Pau dos Ferros (A) and Santa Cruz do Apodi (B) reservoirs.

0.064, respectively) of phytoplankton in the two reservoirs. The correlation Spermam showed that the variables temperature $(r=P=0.46)$, volume $(r$ $=\mathrm{P}=-0.73)$ and transparency $(\mathrm{r}=\mathrm{P}=-0,73-0,74)$ were significantly important in the two reservoirs.

\subsection{Index Assemblage (Q)}

The index assembly (Q) (Figure 6) showed differences between the two studied reservoirs $(\mathrm{F}=17.73, \mathrm{P}=0.001)$. The Pau dos Ferros reservoir classification ranged from bad to tolerable, predominantly state "bad" for almost the entire sample period. This result coincides with higher values of eutrophy and dominance of the functional group $S_{\mathrm{N}}$. Only in February/2012 was recorded a tolerable value, caused by the increase in the contribution of groups D and X1.

In Santa Cruz do Apodi reservoir, the mild state prevailed during most of the period studied, correlated with oligotrophy and mesotrophy conditions of and greater diversity and of different functional groups representation typically of mesoeutrophic environments $\left(\mathrm{K}, \mathrm{S}_{0}, \mathrm{H} 1, \mathrm{C}, \mathrm{F}, \mathrm{J}\right.$,

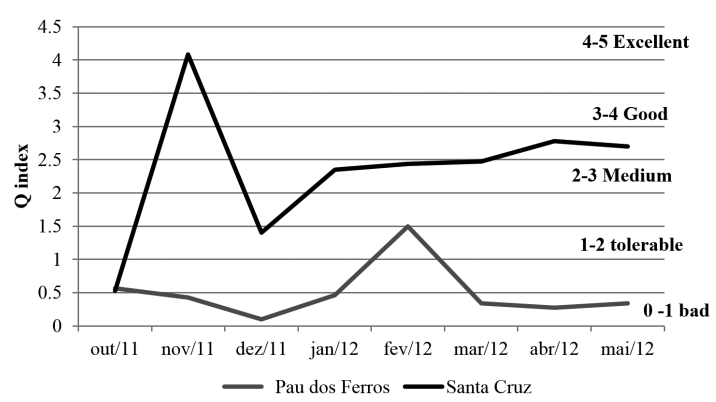

Figure 6. Variation of ecological status according to the application of the index Q in the Pau dos Ferros and Santa Cruz do Apodi reservoirs from October 2011 to May 2012.

P, D and N). The index Q showed smaller values with increasing contribution of the groups $\mathrm{H} 1$ and $\mathrm{K}$, and higher values with increasing contribution from group $\mathrm{F}$.

\section{Discussion}

The entire study period was characterized by a prolonged drought and gradual reduction of average 
monthly volumes of the two reservoirs. The water volume reduction of the reservoirs coincides with decreasing water quality of the reservoirs relative to the index $Q$ and trophic state measured by means of biovolume of the phytoplankton functional group, transparency, chlorophyll-a and total phosphorus. Thus, the higher turbidity, nutrients availability and lower photic zone coincides with the dominance of cyanobacteria functional groups adapted to these environments, alternating with periods of greater photic zone and greater diversity of species.

Studies in Brazilian semi-arid reservoirs show that factors such as the prolonged drought, intense evaporation and long residence time of the water, act decisively in determining the hydrologic conditions of the watershed and is even related to the establishment of eutrophic conditions (Costa et al., 2009). Bouvy et al. (2003) also reported that rainfall events irregularly distributed throughout the year in this region, resulting in intense seasonal fluctuations in water level. These periods are usually characterized by the trophic status change of the system, resulting in poor water quality due to increased turbidity and algal biomass consequently occurring unfeasibility of the use of most reservoirs for various human activities.

In this sense, the temporal response of phytoplankton in reservoirs of Pau dos Ferros and Santa Cruz, despite the difference in their depths, seem to follow the hypothesis of "alternative balance" for shallow lakes proposed by Scheffer (1998) e Scheffer et al. (2001), which shows that abrupt differences in this "balance state" causes different changes in phytoplankton community structure.

The functional groups of phytoplankton identified reveal adjustments and tolerances to meso-eutrophic low latitude environments (Reynolds et al., 2002 and Padisák et al., 2009) and correlated with conditions of eu/hypereutrophy found for the reservoir Pau dos Ferros and trace oligo-mesotrophy to the reservoir Santa Cruz.

In reservoirs of Santa Cruz and Pau dos Ferros, phytoplankton showed distinct patterns of distribution. Pau dos Ferros was categorized as shallow reservoir, in which light and nutrients acted jointly as important limiting factors for phytoplankton (Scheffer, 2004). The turbid waters influenced the composition and biomass of phytoplankton, which showed dominance of the functional group $S_{\mathrm{N}}$ whose relative contribution, covered up to $90 \%$ of total phytoplankton. The species Cylindropermopsis raciborskii, main representative of this group, has ecological success associated with the ability of vertical migration in the water column, tolerance to low light, affinity for phosphorus and ability to fix nitrogen (Padisák, 1993). Moreover, several studies show that $C$. raciborskii acquired several adaptive mechanisms that not only helped to increase their survival but also to make it an invasive species due to present competitive advantage over other phytoplankton species (Sinha et al., 2012), so it has emerged as dominant in eutrophic reservoirs in tropical northeastern Brazil (Bouvy et al., 2000; Huszar et al., 2000; Chellappa \& Costa, 2003), where the high temperatures are recorded throughout the year alongside with the stability of the water column favoring its dominance.(Tucci \& Sant'Anna, 2003).

The increase in the relative contribution of cyanobacteria has been reported in turbid reservoirs where light availability for phytoplankton is low and shows a remarkable increase in water temperature. Further, increased turbidity threatens submerged plant growth and habitat of different fish species (Kosten et al., 2012).

Low light availability in the water column was also evident in other reservoirs in the Brazilian semiarid (Huszar et al. 2000), and turbidity in these environments is also determined by the organic and inorganic fractions of seston (Sousa et al., 2008). In general, inorganic particulate matter carried from drainage basin is a major source of abiogenic turbidity in aquatic environments of semi-arid regions (Thornton \& Rast, 1993), where soils with low organic matter concentration, as is the case of semi-arid Rio Grande do Norte, are susceptible to erosion (Lal, 1985).

It might also be noticed that the low values of biomass coincided with the period in which it was recorded greater mixing zone and transparency, as showed what happened in February 2012, the reservoir of Pau dos Ferros, where these conditions influenced the change in species composition community, increasing the relative contribution of groups $\mathrm{D}$ and $\mathrm{X} 1$ despite constant predominance of $S_{N}$ group. The morphology of the reservoir along with seasonal cycles allowed the "best" adapted species to dominate in certain periods of seasonal succession (Padisák et al., 2006). Therefore, the functional groups described for Pau dos Ferros reservoir are common in eutrophic environments of low latitude, where are registered: high amount of sunlight, high levels of phosphorus, nitrogen and turbidity. 
The reservoir Santa Cruz, with the highest average depth, greater water volume and greater photic zone had lower biomass values and a greater diversity of species, including the participation of the group F, composed of colonial chlorophytes with affinity for clear water in the months where was recorded greater transparency, and diatoms and desmids were also identified the groups $\mathrm{P}$ and $\mathrm{D}$, which are common in shallow aquatic ecosystems, nutrient-rich with muddy and well ventilated waters (Reynolds et al., 2002). Species of green algae J and diatoms $\mathrm{P}$, tolerant to turbidity and high nutrient levels, did not present high biomass, but were related to populations of cyanobacteria.

In depth reservoirs, cyanobacteria generally dominate in the deeper layers. The strong mixing of the water column promotes homogenization of the column causing the cyanobacteria to be dominant or absent due to competitive exclusion (Scheffer et al., 1997).

The model functional group proposed by Reynolds et al., (2002), showed sensitivity to environmental conditions of the reservoirs in this study. The index assembly (Q) developed by Padisák et al. (2006) highlights the importance of including the approach of functional groups in monitoring processes in order to be a different method and sensitive to errors identification.

The assessment of ecological reservoirs status using the $\mathrm{Q}$ index showed a high sensitivity to changes in species composition and functional groups. The reservoir of Pau dos Ferros was categorized as poor for most of the sample period in view of the high biomass of functional groups $S_{N}, S 1$ and H1, in Santa Cruz do Apodi, the lowest index values were recorded when there was dominance of the group M. A similar result was also recorded by Crossetti \& Bicudo (2008) in an eutrophic urban reservoir in southeastern Brazil, they also reported that $\mathrm{Q}$ index values were inversely proportional to the dominance of functional groups $S_{N}, S 1, M, H 1$.

In summary, the index $\mathrm{Q}$ satisfactorily reflected the changes in phytoplankton composition and functional group approach displayed itself as sensitive and responsive to environmental and hydrodynamics changes of the studied reservoirs, revealing itself as a suitable tool for monitoring water quality in the tropical semi-arid region.

\section{Acknowledgments}

The authors thank to CAPES and CNPQ for financial support through projects.

\section{References}

BARBOSA, F.A.R. and PADISÁK, J. Algumas consideraçóes sobre desenho amostral para estudos de longa duração. In E.M. BICUDO and D.C. BICUDO, orgs. Amostragem em limnologia. São Carlos: RIMA, 2004, pp. 343-349.

BECKER, V., CAPUTO, L., ORDÓÑEZ, J., MARCÉ, R., ARMENGOL, J., CROSSETTI, L.O. and HUSZAR, V.L. Driving factors of the phytoplankton functional groups in a deep Mediterranean reservoir. Water Research, 2010, 44(11), 3345-3354. http:// dx.doi.org/10.1016/j.watres.2010.03.018. PMid:20398914

BECKER, V., HUSZAR, V.L.M. and CROSSETTI, L.O. Responses of phytoplankton functional groups to the mixing regime in a deep subtropical reservoir. Hydrobiologia, 2009, 628(1), 137-151. http://dx.doi. org/10.1007/s10750-009-9751-7.

BOURELLY, P. Les algues d'eau douce. 3: les algues bleues et rouges les Eugléniens, Peridiniens et Cryptomonadines. Paris: N. Bouhée, 1985, vol. 3, 512 p.

BOURELLY, P. Les algues d'eau douce: initiation à la systematique. 2: les algues jaunes et brunes, les chrysophycées, pheophycées, xanthophycées et diatomées. Paris: N. Bouhée, 1981, vol. 2, 517 p.

BOUVY, M., FALCÃO, D., MARINHO, M., PAGANO, M. and MOURA, A. Occurrence of Cylindrospermopsis (Cyanobacteria) in 39 Brazilian tropical reservoirs during 1998 drought. Aquatic Microbial Ecology, 2000, 2, 13-27. http://dx.doi. org/10.3354/ame023013.

BOUVY, M., NASCIMENTO, S.M., MOLICA, R.J.R., FERREIRA, A., HUSZAR, V. and AZEVEDO, S.M.F.O. Limnological features in Tapacurá reservoir (northeast Brazil) during a severe drought. Hydrobiologia, 2003, 493(1-3), 115-130. http:// dx.doi.org/10.1023/A:1025405817350.

BRAUN-BLANQUET, J. Pflanzensoziologie. Wien: Springer, 1964, 865 p. http://dx.doi. org/10.1007/978-3-7091-8110-2.

CHELLAPPA, N.T. and COSTA, M.A.M. Dominant and co-existing species of Cyanobacteria from a euthropicated reservoir of Rio Grande do Norte State Brazil. Acta Oecologica, 2003, 24(S1), S3-S10. http:// dx.doi.org/10.1016/S1146-609X(03)00005-5.

CHORUS, I. and BARTRAN, J. Toxic cyanobacteria: a guide to public health consequences, monitoring and management. London: E \& FNSpon, 1999, 416 p.

COLE, G.A. Textbook of limnology. Illinois: Waveland Press, 1994, $412 \mathrm{p}$.

COSTA, I.A.S., CUNHA, S.R.S., PANOSSO, R.F., ARAÚJO, M.F.F., MELO, J.L.S. and ESKINAZISANT'ANNA, E.M. Dinâmica de cianobactérias em reservatórios eutróficos do semi-árido do Rio 
Grande do Norte. Oecologia Brasiliensis, 2009, 13(2), 382-401.

CROSSETTI, L.O. and BICUDO, C.E.M. Adaptations in phytoplankton life strategies to imposed change in a shallow urban tropical eutrophic reservoir, Garças Reservoir, over 8 years. Hydrobiologia, 2008, 614(1), 91-105. http://dx.doi.org/10.1007/s10750008-9539-1.

EUROPEAN PARLIAMENT and COUNCIL OF THE EUROPEAN UNION. Directive 2000/60/ EC of the European Parliament and of the Council of 23 October 2000 establishing a framework for Community action in the field of water policy. Official Journal, 22 Dec. 2000, p. 1-73.

FABBRO, L.D. and DUIVENVOORDEN, L.J. A twopart model liking multidimensional environmental gradients and seasonal succession of phytoplankton assemblages. Hydrobiologia, 2000, 438(1/3), 13-24. http://dx.doi.org/10.1023/A:1004153727140.

HÁJNAL, E. and PADISÁK, J. Analysis of long-term ecological status of Lake Balaton based on the ALMOBAL phytoplankton database. Hidrobiologia, 2008, 599(1), 227-237. http://dx.doi.org/10.1007/ s10750-007-9207-x.

HILLEBRAND, H., DÜRSELEN, C.-D., KIRSCHTEL, D., POLLINGHER, U. and ZOHARY, T. Biovolume calculation for pelagic and benthic microalgae. Journal of Phycology, 1999, 35(2), 403-424. http://dx.doi.org/10.1046/j.15298817.1999.3520403.x.

HUSZAR, V., KRUK, C. and CARACO, N. Steadystate assemblages of phytoplankton in four temperate lakes (NE-USA). Hydrobiologia, 2003, 502(1-3), 97-109. http://dx.doi.org/10.1023/ B:HYDR.0000004273.40488.00.

HUSZAR, V.L.M., SILVA, L.H.S., MARINHO, M., DOMINGOS, P. and SANT'ANNA, C.L. Cyanoprokaryote assemblages in eight productive tropical Brazilian waters. Hydrobiologia, 2000, 424(1), 67-77. http://dx.doi. org/10.1023/A:1003996710416.

HUTCHINSON, G.E. A Treatise on Limnology: introduction to Lake Biology and the Limnoplankton. New York: Wiley, 1967, 1015 p.

JESPERSEN, A.M. and CHRISTOFFERSEN, K. Measurements of chlorophyll-a from phytoplankton using ethanol as extraction solvent. Algological Studies/ Archiv für Hydrobiologie, 1987, 109(3), 445-454.

KOMÁREK, J. and ANAGNOSTIDIS, K. Cyanoprokaryota. 1. Teil: Chroococcales. Berlin: Spektrum Akademischer Verlag, 1998, 548 p. Süsswasserflora von Mitteleuropa, vol. 19/1.

KOMÁREK, J. and ANAGNOSTIDIS, K. Cyanoprokaryota. 2. Teil: Oscillatoriales. München: Elsevier, 2005, 759 p. Süsswasserflora von Mitteleuropa, vol. 19/2.
KOMÁREK, J. and ANAGNOSTIDIS, K. Modern approach to the classification system of Cyanophytes, 4 - Nostocales. Algological Studies/Archiv für Hydrobiologie, 1989, 56, 247-345.

KOSTEN, S., HUSZAR, V.L.M., BÉCARES, E., COSTA, L.S., VAN DONK, E., HANSSON, L.A., JEPPESEN, E., KRUK, C., LACEROT, G., MAZZEO, N., DE MEESTER, L., MOSS, B., LÜRLING, M., NOGES, T., ROMO, S. and SCHEFFER, M. Warmer climates boost cyanobacterial dominance in shallow lakes. Global Change Biology, 2012, 18(1), 118-126. http://dx.doi. org/10.1111/j.1365-2486.2011.02488.x.

KRUK, C., MAZZEO, N., LACEROT, G. and REYNOLDS, C.S. Classification schemes for phytoplankton: a local validation of a functional approach to the analysis of species temporal replacement. Journal of Plankton Research, 2002, 24(9), 901-912. http://dx.doi.org/10.1093/ plankt/24.9.901.

LAL, R. Soil erosion and sediment transport research in tropical Africa. Hydrological Sciences Journal, 1985, 30(2), 239-256. http://dx.doi. org/10.1080/02626668509490987.

LAMPARELLI, M.C. Graus de trofia em corpos d'água do Estado de São Paulo: avaliação dos métodos de monitoramento [Doctoral Dissertation]. São Paulo: Universidade de São Paulo, 2004, 235 p.

LOBO, E. and LEIGHTON, G. Estructuras comunitarias de las fitocenosis planctónicas de los sistemas de desembocaduras de ríos y esteros de la zona central de Chile. Revista de Biología Marina, 1986, 22(1), 1-29.

LOPES, M.R.M., BICUDO, C.E.M. and FERRAGUT, C. Short- term spatial and temporal variation of phytoplankton in a shallow tropical oligotrophic reservoir, southeast Brazil. Hydrobiologia, 2005, 542(1), 235-247. http://dx.doi.org/10.1007/s10750004-8332-z.

LORENZEN, C.J. Determination of Chlorophyll and Pheo-Pigments: Spectrophotometric Equations. Limnology and Oceanography, 1967, 12(2), 343-346. http://dx.doi.org/10.4319/lo.1967.12.2.0343.

LUND, J.W.G., KIPLING, C. and LE CREN, E.D. The inverted microscope method of estimating algal numbers and statistical basis of estimation by counting. Hydrobiologia, 1958, 11(2), 143-170. http://dx.doi.org/10.1007/BF00007865.

PADISÁK, J. Seasonal succession of phytoplankton in a large shallow lake (Balaton, Hungary): a dynamic approach to ecological memory, its possible role and mechanisms. Journal of Ecology, 1992, 80(2), 217230. http://dx.doi.org/10.2307/2261008.

PADISÁK, J. The influence of different disturbance frequencies on the species richness, diversity and equitability of phytoplankton in shallow lakes. 
Hydrobiologia, 1993, 249(1-3), 135-156. http:// dx.doi.org/10.1007/BF00008850.

PADISÁK, J., BORICS, G., GRIGORSZKY, I. and SORÓCZKI-PINTÉR, E. Use of phytoplankton assemblages for monitoring ecological status of lakes within the Water Framework Directive: the assemblage index. Hydrobiologia, 2006, 553(1), 1-14. http://dx.doi.org/10.1007/s10750-005-1393-9.

PADISÁK, J., CROSSETTI, L.O. and NASELLIFLORES, E.L. Use and misuse in the application of the phytoplankton functional classification: a critical review with updates. Hydrobiologia, 2009, 621(1), 1-19. http://dx.doi. org/10.1007/s10750-008-9645-0.

PASZTALENIEC, A. and PONIEWOZIK, M. Phytoplankton based assessment of the ecological status of four shallow lakes (Eastern Poland) according to Warter Framework Directive- a comparison of approaches. Limnologica, 2010, 40(3), 251-259. http://dx.doi.org/10.1016/j.limno.2009.07.001.

PIANKA, E.R. On r- and K-selection. American Naturalist, 1970, 104(940), 592-597. http://dx.doi. org/10.1086/282697.

REYNOLDS, C.S. Phytoplankton assemblages in reservoirs. In J.G. TUNDISI and M. STRASKRABA, orgs. Theoretical reservoir ecology and its applications. São Carlos: International Institute of Ecology, 1999, pp. 439-456.

REYNOLDS, C.S. Phytoplankton periodicity: the interactions of form, function and environmental variability. Freshwater Biology, 1984, 14(2), 111142. http://dx.doi.org/10.1111/j.1365-2427.1984. tb00027.x.

REYNOLDS, C.S., HUSZAR, V., KRUK, C., NASELLI-FLORES, L. and MELO, S. Towards a functional classification of the freshwater phytoplankton. Journal of Plankton Research, 2002, 24(5), 417-428. http://dx.doi.org/10.1093/ plankt/24.5.417.

ROUND, F.E. The taxonomy of the chlorophyta II. British Phycological Journal, 1971, 6(2), 235-264. http://dx.doi.org/10.1080/00071617100650261.

SARMENTO, H., ISUMBISHO, M. and DESCY, J.P. Phytoplankton ecology of Lake Kivu (eastern África). Journal of Plankton Research, 2006, 28(9), 815-829. http://dx.doi.org/10.1093/plankt/fbl017.

SCHEFFER, M. Ecology of shallow lakes. London: Chapman \& Hall, 1998, 357 p.

SCHEFFER, M. Ecology of shallow lakes. Netherlands: Kluwer Academic Publishers, 2004, 332 p. http:// dx.doi.org/10.1007/978-1-4020-3154-0.

SCHEFFER, M., CARPENTER, S., FOLEY, J.A., FOLKE, C. and WALKER, B. Catastrophic shifts in ecosystems. Nature, 2001, 413(6856), 591-596. http://dx.doi.org/10.1038/35098000. PMid:11595939
SCHEFFER, M., RINALDI, S., KUZNETSOV, Y.A. and VAN NES, E.H. Seasonal dynamics of Daphnia and algae explained as a periodically forced predatorprey system. Oikos, 1997, 80(3), 519-532. http:// dx.doi.org/10.2307/3546625.

SIMONSEN, R. The diatom system: ideas on phylogeny. Bacillaria, 1979, 2, pp. 9-71.

SINHA, R., PEARSON, L.A., DAVIS, T.W., BURFORD, M.A., ORR, P.T. and NEILAN, B.A. Increased incidence of Cylindrospermopsis raciborskii in temperate zones-is climate change responsible? Water Research, 2012, 46(5), 1408-1419. http://dx.doi.org/10.1016/j.watres.2011.12.019. PMid:22284981

SOMMER, U. Phytoplankton: directional succession and forced cycles. In H. REMMERT, org. The mosaiccycle concept of ecosystems. Berlin: Springer Verlág, 1991, pp. 132-146. http://dx.doi.org/10.1007/9783-642-75650-4_7.

SOMMER, U., GLIWICZ, Z., LAMPERT, W. and DUNCA, A. The PEG-model of seasonal succession of planktonic events in fresh waters. Algological Studies/Archive Für Hidrobiolgy, 1986, 106, 433-471.

SOUSA, W., ATTAYDE, J.L., ROCHA, E.S. and ESKINAZI-SANT'ANNA, E.M. The response of zooplankton assemblages to variations in the water quality of four man-made lakes in semi-arid northeastern Brazil. Journal of Plankton Research, 2008, 30(6), 699-708. http://dx.doi.org/10.1093/ plankt/fbn032.

THORNTON, J.A. and RAST, W. A test of hypotheses relating to the comparative limnology and assessment of eutrophication in semi-arid man-made lakes. In M. STRASKABRA, J.G. TUNDISI and A. DUNCAN, orgs. Comparative reservoir limnology on water quality management. Netherlands: Springer Netherlands, 1993, pp. 1-24. http://dx.doi.org/10.1007/978-94017-1096-1_1.

TUCCI, A. and SANT'ANNA, C.L. Cylindrospermopsis raciborskii (Woloszynska) Seenayya \& Subba Raju (Cyanobacteria): variação semanal e relações com fatores ambientais em um reservatório eutrófico, São Paulo, SP, Brasil. Revista Brasileira de Botânica, 2003, 26(1), 97-112.

TÜXEN, R. Das System der nordwestdeutschen Pflanzengesellschaften S. Mitteilungen der floristischsoziologischen Arbeitsgemeinschaft, 1955, 5, 155-176.

UTERMÖHL, H. Zur Vervollkommnung der quantitativen phytoplankton-methodic. Mitteilungen Internationale Vereinigung für Theoretische und Angewandte Limnologie, 1958, 9, 1-38.

VALDERRAMA, J.C. The simultaneous analysis of total nitrogen and total phosphorous in natural waters. Marine Chemistry, 1981, 10(2), 109-122. http:// dx.doi.org/10.1016/0304-4203(81)90027-X.

WANG, L., CAI, Q., TAN, L. and KONG, L. Phytoplankton development and ecological status 
during a cyanobacterial bloom in a tributary bay of the Three Gorges Reservoir, China. The Science of the Total Environment, 2011, 409(19), 3820-3828. http://dx.doi.org/10.1016/j.scitotenv.2011.06.041. PMid:21752429

ZOHARY, T., POLLINGHER, U., HADAS, O. and HAMBRIGHT, K.D. Bloom dynamics and sedimentation of peridinium Gatunense in lake kinneret. Limnology and Oceanography, 1998, 43(2), 175-186. http://dx.doi.org/10.4319/ lo.1998.43.2.0175.

Received: 21 February 2014 Accepted: 05 February 2015 